\title{
近代の松島における風景地の整備と眺めの関係
}

\section{The Relationship between Natural Landscape Area Establishment and Characteristics of Scene in Matshushima, in Modern era}

伊藤 弘*

\section{Hiromu ITO}

\begin{abstract}
This study aims to clarify the relationship between the reservation of land to preserve the natural landscape and characteristics of the scenes tourists experienced in Matsushima, in the modern era when the administration took many measures based on travel accounts. Matsushima has been a as popular sightseeing destination since ancient times. As a result, the establishment of natural landscape areas in Matsushima was almost completed in the pre-war period, but only visual scenery was examined. While few tourists experienced these newly designated areas in the pre-war period, after the war, the number of visits to these scenic areas dropped dramatically. Those who came to see the scenery were influenced both by the change in the type of tour, that is, not being able to stay at Matshushima, and by the changes in the landscape from the war. In the post-war period the "Identity of Matsushima" that visitors had discovered became standard in the region and was unified as a common tourist experience. Each visitor experienced the scenery from a different point of view.
\end{abstract}

Keywords: Natural Landscape Area, tour, scene, Matsushima キーワード：風景地，観光，眺め，松島

\section{1. はじめに}

古来より，日本においては沿岸域に名所（風景地）が多く存在 していた。例えば日本三景である松島，安芸の宮島，天橋立など がその代表的な例である。近代になり「日本風景論」や初期登山 家などによって山岳景観が観賞されるようになる1）と，戦前まで に指定された国立公園はほとんど山岳地帯であるなど，もっぱら 山岳地を中心に風景地の整備がなされてきた。一方, 古来よりあ る沿岸域に存在する自然風景地では，近代化とともに新たな観光 施設や道路の整備などが行われてきた。また，国立公園指定運動 などもなされてきた。風景地整備とは，単なる空間の整備とは異 なり，見る対象への働きかけだけではなく，どこから眺めさせる か，またどういう意味ゔけを施すかといった施策も行われるもの である。その結果できあがった空間において旅行者たちがどのよ うな眺めを体験してきたかを知ることは，今後の風景地整備を検 討寸る上で有用といえる。

近代以降の風景地の整備に関しては，例えば国立公園における 集団施設に関する研究2 などが明らかになっている。また，同じ 日本三景でも天橋立を対象に歴史的景観の変遷がどのように变遷 し，それを現在の住民たちがどのように評価しているのかを明ら かにしたもの ${ }^{3)}$ や，古来よりある風景地における風景地計画の変 遷）およびその計画思想と評価されてきた風景との関係をみたも の5) や古来よりある自然風景地に対する風景観の変遷をみてきた ものはある $\left.{ }^{6}\right)$ が，古来よりある風景地がどのように整備され，そ れを受け手(旅行者)がどのような眺めを体験してきたかについて は明らかにされているとはいいがたい。

本研究では, 古来より風光明媚な場所として広く知られてきた 宮城県松島を対象に，様々な政策や施策が展開されたと考えられ る明治以降の行政を中心とした風景地整備の展開と紀行文等から よみとる松島において体験された眺めの関係を明らかにすること を目的とする。

\section{2. 研究方法}

\section{（1）対象地および風景地整備の把握}

対象地は宮城県松島湾である。松島は中世には霊場として雄島 を中心に様々な寺社仏閣が建立された7)。松島湾は日本の海岸景 観の代表でもある多島海景観で有名であり，近世以降は名所とし て知られてきた。近代以降，国立公園制度ができる前に地域制の 自然公園としての性格を有した松島公園計画 8 ) を策定したり，多 島海景観を有する国立公園の景観の規範となるなどしていた9）。 既往研究における風景が生成される過程を参考10)11) に，本研究 では松島においてどのように風景地の整備がなされてきたのかを， 主に行政による視点場の整備・空間およひ環境の変化・空間への 意味づけ12）を指標にとって整理した。視点場の整備は新しい視点 場の出現および視点場の整備（公園化等）を，空間およひ環境の 変化は多島海景観の対象となっている湾内での変化を, 利用者 の働きかけ13) としてみた空間への意味づけは行政によって指定さ れる法制度および当該法制度の趣旨から把握した。なお，花火大 会や現在行われている「かき祭り」などの時期的なイベントは本 研究では対象外とし，恒常的な風景地整備のみを対象とした。以 上は各種史料および地形図からの読み取りにより行った。

\section{（2）対象文献および体験された眺めの把握}

利用者がどのような眺めをどこから体験していたのかを，紀行 文および随筆型の案内書から読み取った。紀行文などは，風景観 を定着させる働きがあるとともに，受け手である旅行者が対象地 をどのように評価してきたのかをみるために既往研究でもいくつ か研究対象とされてきた ${ }^{14 ）} 15$ )。今回対象とする文献は, 既往研究 16）を参考に, 各種電子アーカイブ (青空文庫, 国会図書館近代デ ジタルライブラリ),「明治紀行文学集 (筑摩書房, 1974)」「現代 紀行文学全集 (ほるぷ出版, 1976)」「トラベルガイド (山田晝院, 1999)」「ふるさとへの旅（国際情報社, 1977)」「美しい日本の旅 (学研，1974)」に収監されている紀行文とした ${ }^{17}$ )。これらの文 献から松島の眺めを描写している記述を抜き出した。原則ひとつ

*東京大学大学院農学生命科学研究科 
表 - 1 対象文献

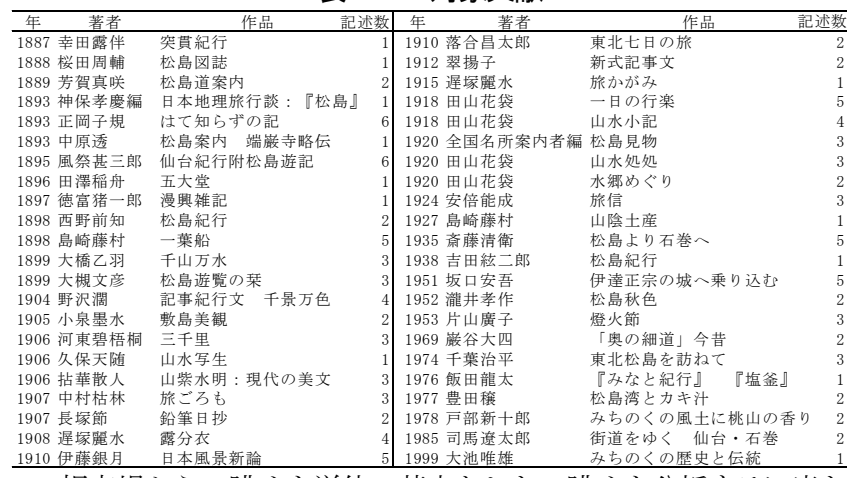

の視点場からの眺めを単位の基本とした。眺めを分析するに当た っては，景観分析モデル18）を援用し，視点場・視対象・景観種類 を指標とした。視点場は対象文献における記述がごこからのもの かを示している。視対象は，具体的に空間の何を記述しているか を示している。景観種類は，それら視対象をどのように記述して いるかを示しており，具体的には眺望景観（視点が固定された眺 め)・シークエンス景観（視点が移動しながら記述される眺め）・ 場の景観（一定範囲の眺めの特徵を示す） 19）・俯瞰景（高所から 見下ろした眺め) に分けた。これらは主に視点と視対象の関係か ら判断される。具体的にはまずシークエンス景観かどうかを判断 した後に，視点場および視対象の位置関係から整理した。例えば 「船行く事飛ぶが如く一島去れば一島迎一迎ふるかと思へば去り， 去るかと見れば随って来たる，前に見た島が後ろになれば忽ち其 象が替はる左に対はんとすれば右に背く20)」のように視対象が移 りゆく様子を示寸記述はシークエンス景観と判断した。

\section{3. 結果}

\section{（1）松島における風景地整備（図 - 1)}

松島では，風景地としての整備の特徵から大きく松島公園計画 が検討され始めた 1900 年以前と戦前期（1950まで）, 戦後期に 時代区分できる。対象となった文献は，1900年以前: 13 文献 (記 述数 33 件, 作者 10 名), 戦前期 : 21 文献（記述数 59 件, 作者 17 名), 戦後期 : 10 文献（記述数 23 件，作者 10 名）と戦前期が 最も多く，田山花袋と遅塚麗水が複数の文章を記している。

藩政時代以前より，松島では湾を囲むようにして四大観と呼ば れる展望地があり，名所となっており，前述したように中世以前 は和歌に詠まれたり霊場として存在していた。近世は「日本三景」 と表現され，風光明媚な場所として意味づけられていた。

1） 1900 年以前

1900 年前後には松島は充分管理されているとは言いがたく, また来訪客も減少してきたころとされている21）。松島湾の整備は 海岸沿いに防波堤や埠頭を設置する程度であった。また，四大観 以外の新たな展望地も整備されていなかった。

2) 戦前期

松島への旅行者誘致を目的に，本多静六監修のもと松島公園経 営計画が策定された22)。そこでは，荒れ果てた森林（具体的には 松林）の植栽が視点場との関係から計画・植栽され23)，湾内の風 景は変化したと考えられる。また，新たな視点場として松島パー クホテルの建設が計画され竣工された（1940 年に火災で焼失）。 さらに，塩窼と松島を結び海岸線沿いを走る塩松観光道路の開通 や海岸線を走る鉄道線（宮城電気鉄道，現仙石線）の開通，多島 海により近接した展望地として新富山や双観山が展望地として見 出されるなど, 新たな視点場が複数設けられた。1902年ころより 松島湾ではカキの人工的養殖に力を入れ始めた。当初は竹・クリ・ ナラなどの枝をたてていた。1920 年ころより半垂下式のたな立法 が採用され主流となり，湾内の風景に変化をもたらした ${ }^{24)}$

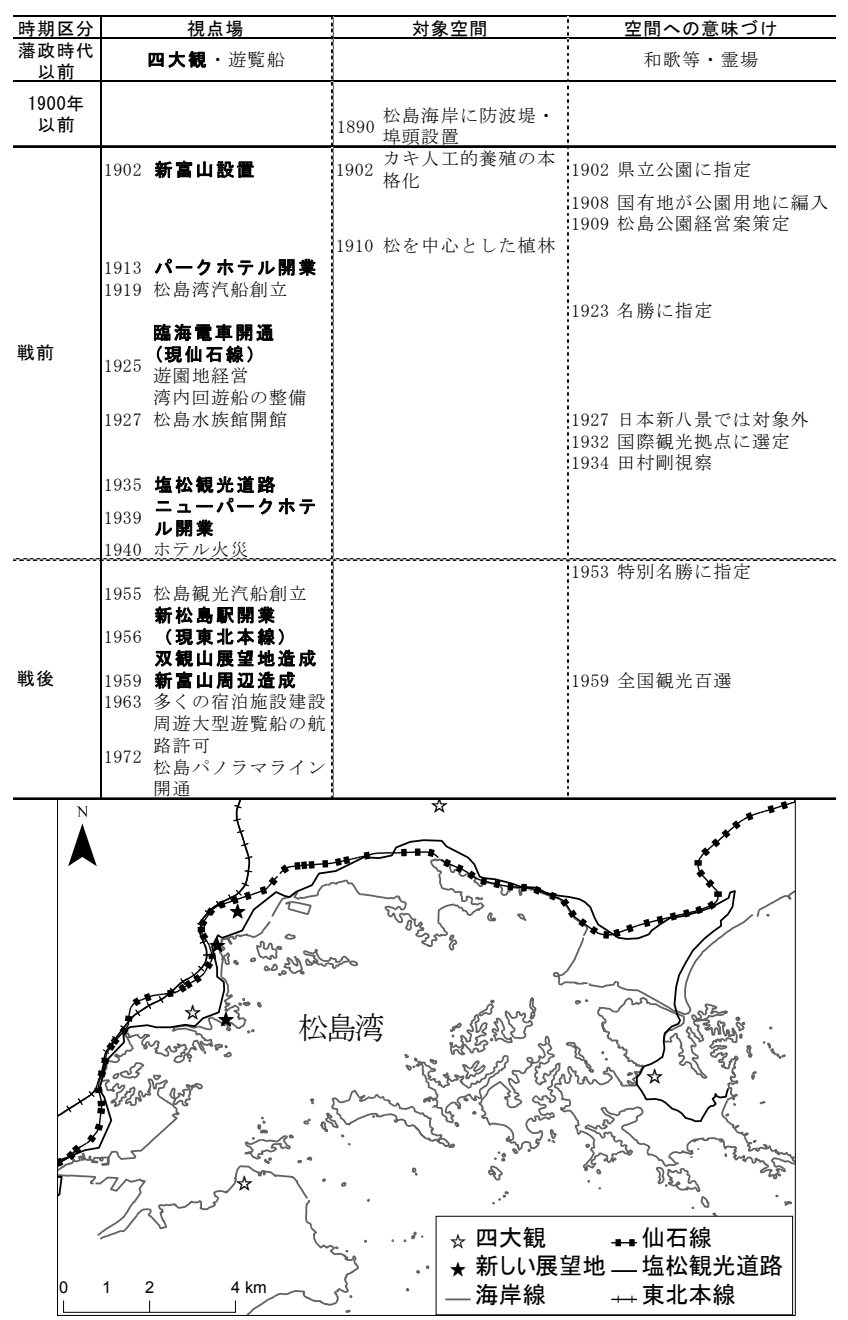

図 - 1 風景地整備の変遷 (上) と視点場の変遷 (下)

この頃松島は，県立公園に指定された後に「四季を通じて自然 の風景の観賞など，実に松島は日本の学界が世界に誇る学術上高 い価值をしめしている」 25) として名勝に, また国際観光拠点に指 定されるなど，行政による県内にとどまらず風景を資源とした日 本を代表する観光地としての意味づけがなされていた。また，こ の頃は国立公園指定請願運動も行われており，そこでは「峯猋起 伏，崎岬ノ参差，湾浦ノ曲折或八奇岩，断崖ノ碧海二望么所眺望 雄大頗儿景趣二富ム。」評しており，いずれも湾の眺めを評価し ていることがうかがえる。

3) 戦後期

輸送力の効率化を目的として山側を走っていた東北本線が海側 に移動し，新たに松島駅が設置された。このようにして，公共交 通機関を利用する場合は，乗車しながら湾を眺めることができる ようになった。しかし，その他の新たな展望地は設けられず，新 富山や双観山周辺の整備など戦前に設けられた視点場の改良にと どまった。また, 1963 年ころより汀線沿いには宿泊施設が多数建 設されるようになり, その収容力は 1980 年ごろには戦前期の軒 数がおよそ 4 倍, 収容力が 10 倍程度となった。これら宿泊施設 によって風景そのものも変化した ${ }^{26)}$ 。しかし，観光形態としては 依然として宿泊を伴う旅行者数は少なかった ${ }^{27}$ 。「日本的な自然美 を代表するものとして，また長く景観美を保護する必要から」28) 特別名勝指定や, 全国観光百選への入選など, 意味づけも戦前の ものを踏襲・強化するにとどまっている。また湾の周辺南西沿岸 部には仙台火力発電所が設けられ，これも風景に変化をもたらし $た^{29)}$ 。 
表 - 2 視対象記述頻度

\begin{tabular}{|c|c|c|c|c|c|c|}
\hline \multicolumn{2}{|c|}{ 時代 } & \multicolumn{5}{|c|}{ 記述数の多い視対象 } \\
\hline 1900 年 & (33) & 島 (27) & 海 (15) & 松（14） & 山 (10) & 湾 (6) \\
\hline 戦前期 & (59) & 島 (38) & 海 (27) & 松 (22) & 時節 (17) & 湾 $(10)$ \\
\hline 戦後期 & (23) & 海 (11) & 島 (10) & 産業（7） & & \\
\hline
\end{tabular}

表 - 3 数量化 3 類結果

\begin{tabular}{|c|c|c|c|c|c|}
\hline & 第1軸 & 第 2 軸 & 第3 軸 & 第 4 軸 & 第5 軸 \\
\hline 全体 & 4.28 & 0.01 & 0.12 & 0.10 & -0.23 \\
\hline 島 & -0.26 & -0.13 & -0.55 & 0.09 & -0.38 \\
\hline 海 & -0.25 & -0.09 & 0.29 & -0.50 & -0.34 \\
\hline 松 & -0.26 & -0.47 & -0.84 & 0.63 & -1.01 \\
\hline 時節 & -0.02 & -1.03 & -1.22 & -0.56 & 2.85 \\
\hline 湾 & -0.23 & 0.08 & 2.07 & -1.53 & 0.50 \\
\hline 山 & -0.23 & 1.07 & 0.61 & -1.77 & -0.52 \\
\hline 建物 & -0.20 & 3.95 & -0.51 & 1.42 & 1.17 \\
\hline 産業 & -0.32 & -0.85 & 2.25 & 2.42 & 0.65 \\
\hline 寄与率 & $28.4 \%$ & $15.5 \%$ & $13.9 \%$ & $12.0 \%$ & $10.8 \%$ \\
\hline
\end{tabular}

$\begin{array}{llllll}0 \% & 20 \% & 40 \% & 60 \% & 80 \% & 100 \%\end{array}$

\section{0年以前 $\quad$\begin{tabular}{ll|l|l|}
9 & 8 & 2 & 4
\end{tabular} \\ 戦前期 17 \begin{tabular}{ll|l|l|l|}
17 & 5 & 13 & 5
\end{tabular}

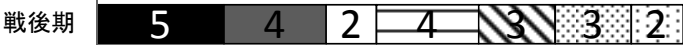 \\ 、島と松、島と海、時節と環境 口産業と環境 、全体 \\ 曰地形、建物と環境 口時節のみ、建物のみ、産業のみ}

図 - 2 時代ごとの視対象タイプ

\section{（2）紀行文による眺めの変遷}

近代以降紀行文による松島の眺めは，空間を視覚的に捉えるも のばかりであり，その捉え方に差異がみられた。古来より和歌な どに歌われてはいるが，歌枕などと関係した記述はなかった。

\section{1) 視対象}

いつの時代でも海と島が主な視対象であったが，戦前期までは 島の記述が最も多かったのに対し，戦後期は海と島がほぼ同数記 述されており，若干海の記述の方が多い。また，産業が戦前期ま でと比べて相対的に多く記述されており，戦前期までに多く記述 されていた湾および山々（戦前期にも 8 件）などの地形的特徴や 松の記述が少なくなっている（表－2）。

視対象は複数の組み合わせによって構成されているため, 数量 化3類およびクラスター分析を用いて視対象をタイプ分けした。 数量化 3 類を行った結果（表 - 3)，第 5 軸までに累積寄与率が $80.38 \%$ となった。第 1 軸は全体が正, 残りの要素が負にあること から「全体性 (全体を対象としているかどうか)」, 第 2 軸は建物・ 山が正，時節（朝日や夕日，雪など）・産業が負になっていること から「内陸性（内陸のものを対象としているかどうか)」, 第 3 軸 は産業・湾が正，時節・松が負になっていることから，地表から 高さを伴って存在する「地物性(地物を対象としているかどうか)」, 第 4 軸は産業・建物が正，山・湾が負にあることから「地形性 (地 形を対象としているかどうか)」，第 5 軸は時節・建物が正，松が 負にあることから「特定性（地域や時節を特定するものを対象に しているかどうか)」と解釈された。これら 5 軸の因子得点を用 いてウォード法によるクラスター分析によりタイプ分けした結果, 島と松を記述している「島と松」，島と海を記述している「島と海 (17 件)」時節と湾内の様々な自然環境を記述している「時節と 環境 (17 件)」養殖などの産業と湾内の自然環境を記述している 「産業と環境 (13 件)」特定の要素は記述せずに全体を捉えてい る「全体 (11 件)」湾周辺の山々などを記述している「地形 (10 件)」建築物と自然環境を記述している「建物と環境 (9 件)」月 や夕暮れなどのみ記述している「時節のみ ( 2 件)」建築物だけを 記述している「建物のみ (3 件)」産業だけを記述している「産業 $\begin{array}{llllll}0 \% & 20 \% & 40 \% & 60 \% & 80 \% & 100 \%\end{array}$

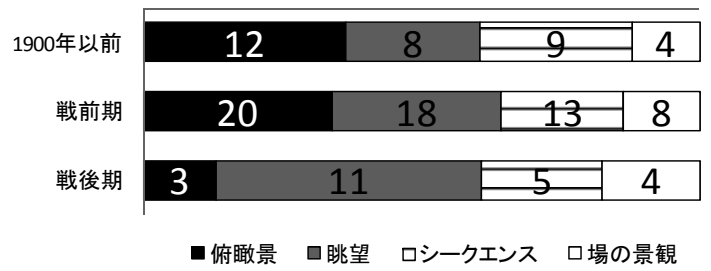

図 - 3 時代ごとの景観種類

$\begin{array}{llllll}0 & 20 \% & 40 \% & 60 \% & 80 \% & 100 \%\end{array}$

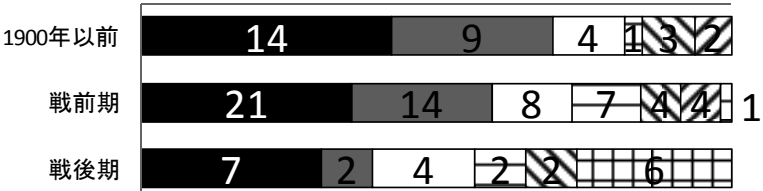

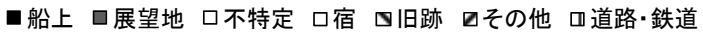
図 - 4 時代ごとの視点場

のみ (2 件)」の 10 タイプに分けることができた。これらのタイ プと時代区分の関係をみると (図 - 2), 必ずしも時代ごとに有意 な差異があるとはいえないが，戦前までは「島と松」の記述が多 い。1900 年以前では「島と海」が次いで多いのに対し，戦前期で は「時節と環境」が次いで多い。戦後期になると，「島と松」は最 も多いものの, 他のタイプと比べてほとんど記述数に差はなく, 戦前までに比べて多様に分かれている。また，戦前までになかっ たタイプとして自然環境を描写せずに建築物や産業のみを描写す る「建物のみ」「産業のみ」が新たに出現している。逆に「地形」 「建物と環境」「時節のみ」はみられなくなっている。

2) 景観種類 (図-3)

戦前期までは俯瞰景が最も多い。1900 年以前は俯瞰景に次いで シークエンス景観が多かったのに対し, 戦前期は眺望景観が 2 番 目に多い。一方，戦後期には俯瞰景は減少し最も少ない。逆に眺 望景観が最も多く, およそ半数の記述が眺望景観であり, その他 の種類はほぼ同数であった。

3）視点場（図 - 4)

各時代を通して最も多いのは船上からの記述であった。戦前期 までは船上に次いで展望地が多かったのに対し, 戦後期は展望地 からの記述は極端に少なくなり，道路や鉄道（主に道路）からの 記述が増加した。また, 雄島（かつて松島が霊場として知られて いた頃の中心とされている島）や福浦島などの島や地蔵堂，場所 を特定できない山上など「その他」からの記述がなくなっている。 戦前期では，3 ケ所以上の視点場からの記述が 21 文献中 12 文献 (1900 年以前 : 13 文献中 5 文献, 戦後期 : 10 文献中 3 文献) と その割合が多く, 域内を周遊する観光形態の傾向が強いことがう かがえる。逆に戦後期は, 域内を周遊しない観光形態の傾向が強 いことが示唆される。

戦前期においては古来より知られていた四大観からの眺めが多 く，既に設置されていたにも関わらず新たに整備された展望地か らの記述は 5 件（15 件中）にとどまっている。また，いずれの時 代にも視点場が特定できない記述が多い。戦前期だけは宿からの 記述も多いが，この時代に新しく建設されたパークホテルからの 記述は 1 件のみであった。

4）体験された眺めの変遷

以上，個別にみてきた眺めを，どこから何をどのように眺めて いたのか総合的にみたうえで, 体験頻度の高い眺めを抽出する (表

-4)。まず眺めを表す視対象と景観種類の組み合わせを中心に整 理すると, 1900 年以前は島と松のシークエンス景観と島と海の俯 
表 - 4 時代ごとの体験頻度の高い眺めの変遷

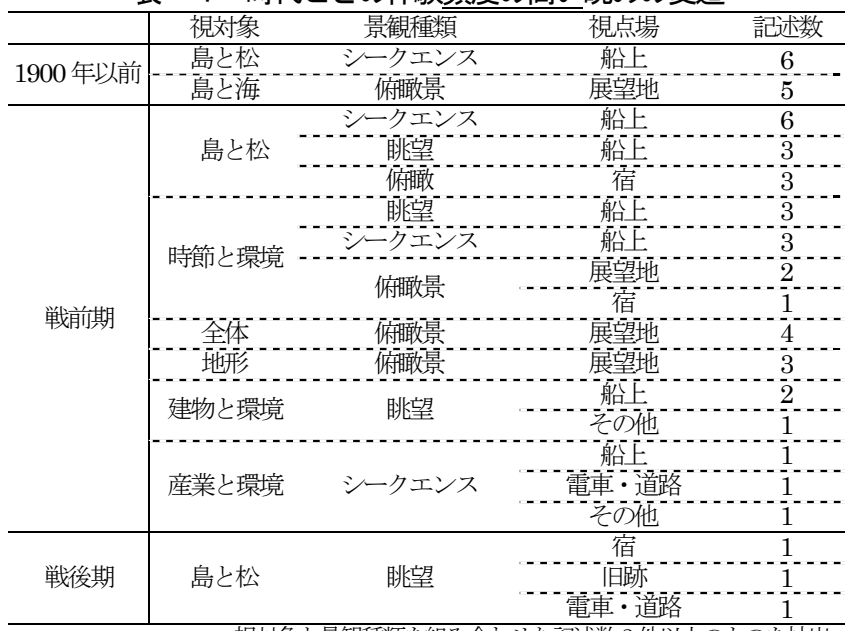

視刘象と景観種類を組み合わせた記述数 3 件以上のものを抽出

瞰景が多く，視点場はそれぞれ船上と展望地のみである。戦前期 になると，島と松のシークエンス景観・俯瞰景・眺望，時節と環 境の眺望・俯瞰景・シークエンス景観，全体の俯瞰景，地形の俯 瞰景, 建物と環境の眺望, 産業と環境のシークエンス景観が多い。 環境に時節や建物、産業を組み合わせた視対象は同じ景観種類で も複数の異なる視点場から記述されている。逆に島と松は景観種 類と視点場が一対一対応している。戦後期は島と松の眺望だけが 多く, 複数の異なる視点場から記述されているが，その数は少な く視点場ごと来訪者ごとに体験された眺めは異なっていたといえ る。上記変化は逆にいえば同じ視点場であっても 1900 年以前と 戦前期の視対象および景観種類の組み合わせは異なっていること を示す。例えば船上からは 1900 年以前はほぼ島と松のシークエ ンス景観の記述であったのに対し，戦前期は島と松のシークエン ス景観に加えて時節と環境のシークエンス景観および朓望景観と 島と松の眺望景観が多く記述されているなど多様化している。

前述の通り松島においては，宿泊を伴わない観光形態の傾向が 顕著であることを30）31）考えると，こうした観光形態も各文献の 著者たちが体験した眺めに影響を及ぼしていることが考えられる。

\section{4. まとめ}

\section{（1）風景地整備と体験される眺め}

1900 年以前は, 展望地や船上から島を中心とした眺めを体験す ることが多く，その眺め方はやや固定されていた。実際の空間も 藩政時代より変化はほとんどなく湾ではカキの養殖が始まったが, それは眺めの対象にはなっていなかった。戦前期になると，いく つか特徴的な眺め方が行われるようになった。新たに整備された 視点場からの記述が少なく視対象にも変化がないこと, 複数の従 来ある視点場から記述した文献が増えたことを考えると，これは 湾内の島々への植林や養殖産業の発達という風景の変化に加えて 新たな視点場の創出という風景地の変化というよりも，域内を周 遊する傾向が出てきたという観光形態の変化によるものであった。 また，全体の記述や時節の記述など場の景観や特定の要素だけで はなく松島湾全体も記述しており，著者たちの風景観（どのよう な眺めに価值を見出すか）も変化したといえる。こうして,観光形 態の変化と著者たちの風景観にも変化が生じ，体験された眺めが いくつかの種類に収斂され，松島を代表する眺め（松島らしさ） が多様化したといえる。戦後期には，宿および展望地からの記述 が減少し道路・鉄道からの記述が増加していることから，今回と りあげた文献の著者たちは車を利用して別の場所に移動する宿泊 を伴わず域内を周遊しない観光形態をとっており，それが体験さ れる眺めに影響を及ぼしたと考えられ，複数の来訪者によって共
有され，地域の規範となる多様な「松島らしさ」は再び一元化さ れ,体験した眺めは視点場ごと来訪者ごとに異なるものとなった。 一方，産業や建物が相対的に多く記述されるようになっており， 戦前期と比べて風景観にも変化が現れたことがうかがえる。また, 地形や時節など自然条件に関する記述はなくなり産業や建物だけ の記述がみられるようになった。戦後期はこうした風景観の変化 に風景地の整備が充分対応してきたとはいいがたい。

\section{（2）今後の風景地整備に向けて}

本研究でみてきたとおり, 観光形態が風景観と合致すると, い くつかの新たな規範となる眺めが生まれた。すなわち, 新たな風 景地の整備というよりも既存の空間での新たな風景観と観光形態 の組み合わせによって新たな眺めを享受することが可能になると 考えられる。一方, 風景観の変化と車での移動を主とした観光形 態の変化によって松島の一部を切り取って観賞するかのような眺 めが享受されるようになっている。こうした現象が道路や鉄道の 整備など対象地へのアクセス向上によるものなのか，そもそもそ ういった風景観に基づくものかは不明である（双方の影響による ものとも考えられる)。風景地を整備するその主たる目的が風景の 鑑賞であることを考えると，風景地へのアクセス向上を図る整備 が, その目的に合致するから゙うか慎重に検討していく必要がある。 また，松島においては前述した通り戦後期に規範となるような眺 めが減少していることから，風景地においてどのような新たな眺 めを提供し，そこにどのような意味づけを施すかといった目標像 も観光形態と併せて検討していく必要がある。

\section{補注及び引用文献}

1）田中正大 (1981)：日本の自然公園 自然保護と風景保護, 相模選書, 209 2）堀繁 (1994)：わが国の国立公園の計画管理の実態とその変遷に関する研究 (2)： 利用計画と管理，東京大学農学部演習林研究報告，137-209

3）深町加津絵・奥敬一 (2004): 天橋立における歴史的景観の変遷と地域住民の景観 評価に関する研究, ランドスケープ研究 67(5)

4）手嶋潤一 (2006): 日光の風景地計画とその変遷, 随想舎, 398pp.

5）山口敬太・水谷肇・出村嘉史・川崎雅史・樋口忠彦 (2006) : 昭和初期の嵯峨にお ける風景の価值評価に関する研究，景観・デザイン研究論文集,1，185-192

6) 西田正憲 (1999) : 瀬戸内海の発見，中公新書，263pp

7）川村 晃生著・浅見 和彦著（2006）：壊れゆく景観，慶應義塾大学出版会，29-37

8) 前掲書1), 76

9）伊藤弓 (2010) : 大正から戦後にかけての国立公園行政における多島海景観として の松島の評価，日本建築学会論文集 656，2391-2396

10）篠原修 (1998)：景観用語辞典, 彰国社, 31

11）エドワード・レルフ (1999) : 場所の現象学, 筑摩書房, 341pp

12）主体が空間の有する意味や機能に価值を見出すことが価值づけである。本研究て は行政による法制度の指定によって利用者にとっては「行政によって『価值がある』と 認められた空間」といら意味が付与されると考え、「空間の意味ゔけ」とした

13）篠原修（1998）：景観用語事典，彰国社，80-81

14）山口敬太・出村嘉史・川崎雅史・樋口忠彦 (2010) : 近世の紀行文にみる嵯哦野 における風景の重層性に関する研究，土木学会論文集 D,66(1),14-26

15）西田正憲 (2004) : 近世の紀行文等にみる山岳表象の特質, ランドスケープ研究 68 (5), 407-410

16）小野良平 (2009)：用語「鎮守の森」の近代的性格に関する考察，ランドスケー プ研究 73(5), 671-674

17）他にも各種紀行文を確認したが，本研究のデータとして適しているものは示した 文献であった

18) 前掲書10)

19）場の景観は，「(文頭で) 云ぶ゙からず述ぶべからざるの妙島あり奇松あり（野沢 潤 (1904) : 記事紀行文 千景万変)」のように視点場が特定されない記述となる。

20）芳賀真咲 (1889)：松島道案内

21）（財）宮城懸史刊行会（1955）: 宮城懸史 16.観光，2

22）宮城県内務部 (1915) : 松島公園経営案

23） 宮城県内務部（1915）: 松島公園経営報告書，96-100

24）松島町誌編纂委員会編 (1960) : 松島町誌，232-233

25）前掲書24)，218

26）松島町史編纂委員会編(1991）: 松島町史＼cjkstart通史編II，280-290

27）（社）日本観光協会（1984）: 全国観光動向

28）宮城県教育委員会編（1975）: 特別名勝「松島」保存管理計画策定書，宮城県文 化財調査報告書. 第 45 集, 1

29）浅見和彦・川村晃彦 (2006) : 壊れゆく景観慶應義塾大学出版会, 36

30）前掲書24)，224-225

31) 前掲書27) 